American Journal of Biochemistry and Biotechnology 5 (4): 162-169, 2009

ISSN 1553-3468

(C) 2009 Science Publications

\title{
Effect of Drought Stress and Methanol on Yield and Yield Components of Soybean Max (L 17)
}

\author{
${ }^{1}$ Mojtaba Mirakhori, ${ }^{2}$ Farzad Paknejad, ${ }^{3}$ Foad Moradi, ${ }^{2}$ Mohammadreza Ardakani, \\ ${ }^{4}$ Hossein Zahedi and ${ }^{1}$ Parisa Nazeri \\ ${ }^{1}$ Islamic Azad University, Member of Young Researcher Club, Karaj Branch, Iran \\ ${ }^{2}$ Islamic Azad University, Karaj Branch, Iran \\ ${ }^{3}$ Institute Biotechnology Research Center, Karaj Branch, Iran \\ ${ }^{4}$ Islamic Azad University, Islamshahr Branch, Iran
}

\begin{abstract}
Problem statement: In order to evaluate drought stress and methanol on yield and yield components of soybean in field experiments with factorial experiment inform of a randomized complete block design with three replication in field faculty of agricultural of Islamic Azad University Karaj, at 2008. First factor were sprayed aqueous solutions 0 (control), 7, 14.21, 28 and 35\% (v/v) methanol by 3 times during growth season of soybean with 12 days intervals on shoot of soybean. Second factor were drought stress condition in two levels 40 and $70 \%$ base of depletion available soil moisture. Approach: This study measured grain yield, biomass HI, 1000 grain weigh, high plants, number of branch, diameter of stem, number of pod on plant, number of hollow pod. Results: Results of the experiment indicated that significant differences exist $(p>0.05)$ between sprayed of solution methanol on parameters. Results also showed that was significant $(\mathrm{p}>0.05)$ differences between effect of drought stress levels on measured parameters. Effect of aqueous solution 14, 21 and $28 \%(\mathrm{v} / \mathrm{v})$ methanol on measured parameters was greater than other treatments. Foliar application of 14 and $21 \%(\mathrm{v} / \mathrm{v})$ methanol increased leaf area index, crop growth rate, pod growth rate, leaf area duration, pod yield, seed yield, weight of 1000 kernel, mature pods per plants. Conclusion: The lowest grain yield obtained in control and $35 \%(\mathrm{v} / \mathrm{v})$ methanol treatments. Interaction effects were not significant.
\end{abstract}

Key words: Drought stress, methanol, growth, yield components, soybean

\section{INTRODUCTION}

Generally, drought is one of the limiting crop production factors in dry area ${ }^{[4,7]}$. Moran et al. ${ }^{[28]}$ reported soybean production is severely affected by water deficit during pod filling grain formation. Since Iran country import oil and protein crops, soybean production is essential and thus it is important to carry out research and investigation on forgoing plant for collection and its development ${ }^{[8]}$. Drought stress is one of the important soybean growth limiting factor which decreases plant growth during vegetative stage. Many researchers believe that amount of crop water use determine plant growth and development. Meanwhile plants may injure under non optimal access of water at any stage $e^{[4,7,8]}$. Taking this point, many researchers tend to use growth regulators to improve crop growth and production. The first step to achieve high yield per unit area is high production of dry matter because almost $90 \%$ of plant dry weight is resulted from $\mathrm{CO}_{2}$ assimilation during photosynthesis. Methanol spry is a method which increases crop $\mathrm{CO}_{2}$ fixation in unit area. Recent investigation showed that $\mathrm{C}_{3}$ crops yield and growth increased via methanol spray and methanol may act as C source for these crops $^{[1,17,18,29,31]}$. Generally, the major roll of this substance is to prevent negative effects of stresses on crops via reduction of photo respiration ${ }^{[26,37]}$. Application of methanol, ethanol, propanol, botanol and amino acids such as glycin, glutamate and spartat materials is an approach for increasing $\mathrm{CO}_{2}$ concentration in plants ${ }^{[2,23,37,38]}$. The major source of methanol production in plant is cellular pectin demethylation. Such volatile organic compound i.e., methanol exists leaves via stomata ${ }^{[10]}$ and it is obvious that plant tissues metabolize methanol ${ }^{[12,32]}$. Methanol sprayed on plants, enters their tissues rapidly and can be found in Serin structure following influence on plant carbon metabolism ${ }^{[13]}$. Increase of methanol concentration in plant issues positively affects carbon fixation efficiency and cause to leaf enlargement via up regulation of pectin methyl esterase gene ${ }^{[13,35,38]}$. Symbiotic bacteria named Methiol trophic bacteria live

Corresponding Author: Mojtaba Mirakhori, Islamic Azad University, Member of Young Researcher Club, Karaj Branch, Iran 
on most of plant leaves ${ }^{[2,19,20]}$. These bacteria receive methanol extruded from plant leaves and in return donate precursor of some hormones such as Auxin and cytokinin which involve in leaves growth and development. Also, these bacteria are associated with nitrogen metabolism in plants through production of bacterial urea ${ }^{[10,19,21]}$. Thus nitrogen metabolism is higher in plants sprayed with ethanol ${ }^{[3,16]}$. Rabinson and Jonse $^{[37]}$ declared that glycin has effective roll in drought tolerance. Glycin protective roll is not limited just to its osmosis protection roll but is involved other stress induced physiological response ${ }^{[23]}$. Some investigation related to effect of methanol spry on crop growth and yield indicated that spry of ethanol on water deficit exposured crops increases their biomass but decreases biomass of control plants ${ }^{[31,34,36,38]}$. It shows that methanol can affect crop $\mathrm{CO}_{2}$ assimilation ${ }^{[38]}$. Photo respiration can be minimized with methanol spry, since $25 \%$ of carbon wastes during photo respiration $^{[9,26,38]}$. That is because methanol is absorbed in plant and rapidly metabolized to $\mathrm{CO}_{2}$ in plant tissue $^{[13]}$ due to smaller size of methanol rather than $\mathrm{CO}_{2}$. Spray of methanol on drought encountering plants prevents loose of their biomass ${ }^{[5,6,13]}$. Safarzade ${ }^{[38]}$ reported that $20 \%(\mathrm{v} / \mathrm{v})$ methanol spray increases leaf area index, crop growth rate, pod growth rate, radiation use efficiency, pod and grain yield, 100 grain weight, number of ripened pod and grain protein of peanut. According to Benson Nonomura ${ }^{[31]}, 10-50 \%$ (v/v) methanol spray increase plant growth and yield due to reduction of photo respiration rate and increase in cell turgescence as well. Also methanol spray delay leaf senescence via effect on ethylene which can prolong photosynthetic active period ${ }^{[16]}$. It is necessary to dark for a few hours following methanol spray in order to better absorption. Also, methanol spray increases soybean yield by $16-22 \%$ as a result of increase in photosynthetical capacity of plant at reproductive stage due to increase in amount of $\mathrm{CO}_{2}{ }^{[24]}$. According to Andres $^{[3]}$, methanol spray increases activity of FBPase which is one of the important enzymes controlling photosynthesis. In addition, Hemmingle ${ }^{[17]}$ reported that methanol spray increases carbon assimilation efficiency. Yield of $\mathrm{C}_{4}$ plants less affected by methanol spray because of different leaf internal structure and $\mathrm{CO}_{2}$ enrichment in mesophyll cells ${ }^{[32,11]}$. Consider increase in growth of wheat, radish, pea, peanut and tomato as a result of methanol spray has reported too ${ }^{[34,35,38]}$. It should be considered that time and method of methanol application in field is very important ${ }^{[32,34,35]}$. The aim of this research, thus, is to evaluate response of soybean yield and yield component to drought stress and methanol spray.

\section{MATERIALS AND METHODS}

In order to evaluate drought stress and methanol on yield and yield component of soybean (L 17), a field experiment was conducted based on factorial experiment in form of a randomized complete block design with three replications in field of agriculture faculty of Islamic Azad University Karaj, location Mahdasht $\left(35^{\circ} 45^{\prime}\right.$ north and $51^{\circ} 6$ ' east with altitude of $1313 \mathrm{~m}$ above sea level). Soil texture was clay loam and PH and salinity through depth of $30 \mathrm{~cm}$ was 7.5 and 5.5 $\left(\mathrm{ds} \mathrm{m}^{-1}\right)$, respectively. First factor were spayed aqueous solutions 0 (control), 7, 14, 21, 28 and $35 \%$ (v/v) methanol, second factor were drought stress condition in two levels 40 and $70 \%$ based on depletion of available soil moisture. Methanol spray was applied 3 times during growth season of soybean with 12 day intervals on shoot of soybean. The first spray applied 60 days after sowing and the other applied 75 and 90 days after sowing. Methanol spray was carried out in a way that all above ground parts of soybean plant were covered. Back engine sprayer with a capacity of $12 \mathrm{~L}$ was used for spray and sprinkler was held $40 \mathrm{~cm}$ above the plants. Time of spray which is very important was 4-8 pm of each given days. For the factor (drought stress) we use chalk block that regulated with calibration curve in (Fig. 1). Flooding irrigation was conducted and all of treatments were irrigated completely prior to 5th and 6th leaf emergence. There were 6 rows with the length of $5 \mathrm{~m}$ in each plot. Distance between two rows was $60 \mathrm{~cm}$ and between two plants on each row was $10 \mathrm{~cm}$. There were two intact rows between each plot in order to prevention of water leakage. Plugging, two multiply disk and leveler were applied to prepare seed bed.

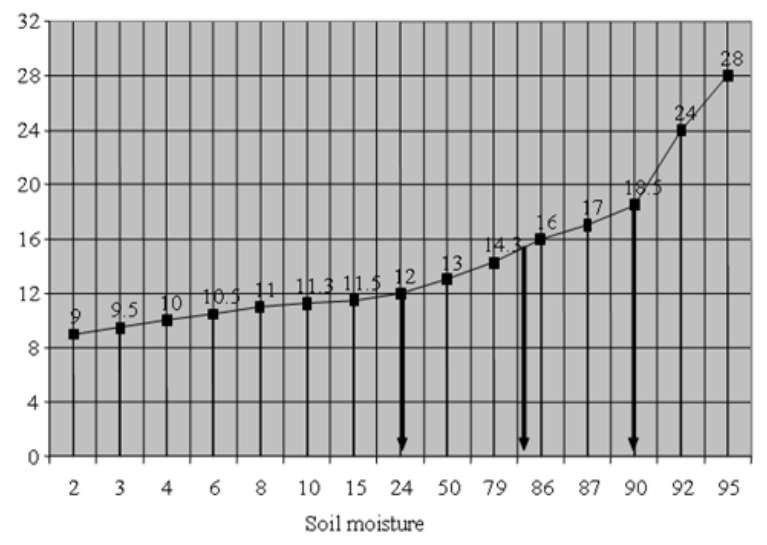

Fig. 1: Curve calibration chalk block 
After seed bed preparation and prior to cultivation time, $50 \mathrm{~kg}$ super phosphate triple and $60 \mathrm{~kg}$ urea were utilized based on result of soil analysis. Soybean seeds were antiseptic and sown in depth of $5 \mathrm{~cm}$ in May 2008. There were 2-5 seeds beside each other and they were thinned at three leaves stage to obtain plant density of 15-20 plant per $\mathrm{m}^{2}$. All plots were harvested on September 2008. Grain yield, biomass, 1000 grain weight, harvest index, number of pod on plant, number of hollow pod, plant height and stem diameter were studied. In other to evaluation of grain yield, HI and 1000 grain weight, $3 \mathrm{~m}^{2}$ of each plot were harvested. Also, 10 plants were selected randomly to determine morphological traits as plant height, stem diameter, number of matured and hollow pod and number of branches. Statistical analysis of data related to investigated traits was done using SAS LSD (5\%) was performed for treatment mean comparison.

\section{RESULTS}

Results of data analysis (Table 1) showed that drought stress had significant $(5 \%)$ effect on grain yield, plant height, 1000 grain weight, number of branches plant biomass, stem diameter and number of matured and hollow pod but not height of plant below first branch and harvest index. Based on result of mean comparison, the height (1754 kg/ha) and the lowest $(1438.98 \mathrm{~kg} / \mathrm{ha})$ amount of yield were related to $\mathrm{T} 1$ (40\% soil water depletion) and T2 (70\% soil water depletion) treatment, respectively (Fig. 1). Meanwhile, T2 treatment had $16.4 \%$ more yield than T2 treatment.
Since drought stress was exerted from primary growth stages, T2 treatment received less water than T1 and hence drought stress reduced yield component such as biomass, seed yield and plant height (Fig. 4). Total biomass was reduced considerably due to reduction of plant height. Result of data analysis (Table 1) showed that methanol had significant $5 \%$ effect on grain yield, plant height, 1000 grain weight, number of branches, plant biomass, stem diameter and hollow pod but not height of plant below first branch and harvest index. Result of present research showed that grain yield of 14 and $21 \%$ methanol were highest, 1623.9 and $1811 \mathrm{~kg}$ $\mathrm{ha}^{-1}$ respectively (Fig. 2), and had significant differences with yield of control plants and other treatment (Table 2). Application of 14 and $21 \%$ methanol increased yield 13.02 and $26.11 \%$ compared with control plant. Increase in grain yield resulted from increase in 1000 grain weight, height, biomass, number of branches and number of pod per plant.

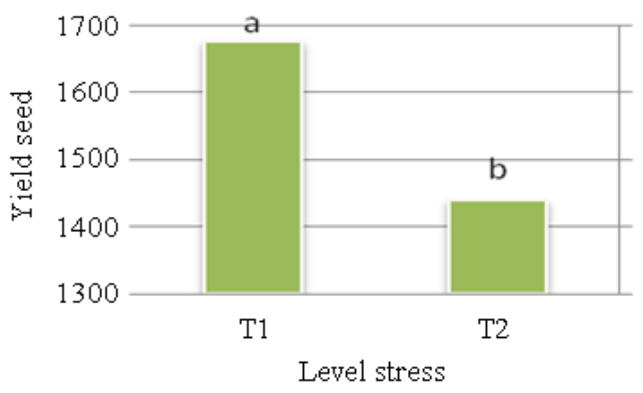

Fig. 2: Effect of drought stress on yield seed

Table 1: Analysis of variance Effect of drought stress and methanol yield and yield components of soybean

\begin{tabular}{|c|c|c|c|c|c|c|c|c|c|c|c|}
\hline SOV & DF & $\begin{array}{l}\text { Seed } \\
\text { yield }\end{array}$ & Height & $\begin{array}{l}\text { No. of } \\
\text { pod }\end{array}$ & $\begin{array}{l}\text { No. of } \\
\text { hollow pod }\end{array}$ & $\begin{array}{l}\text { Harvest } \\
\text { index }\end{array}$ & $\begin{array}{l}\text { Diameter } \\
\text { stem }\end{array}$ & $\begin{array}{l}\text { No. of } \\
\text { branch }\end{array}$ & $\begin{array}{l}\text { Height of } \\
\text { first branch }\end{array}$ & $\begin{array}{l}\text { Total } \\
\text { biomass }\end{array}$ & $\begin{array}{l}1000 \text { seed } \\
\text { weight }\end{array}$ \\
\hline Replication & 2 & $3602.2 \mathrm{~ns}$ & $24.6 \mathrm{~ns}$ & $298.00 *$ & $6.45^{*}$ & $147.90 *$ & $0.90 \mathrm{~ns}$ & $1.38 \mathrm{~ns}$ & $29.80 \mathrm{~ns}$ & $4968677.0^{*}$ & $52.4 \mathrm{~ns}$ \\
\hline Drought Stress & 1 & $503863.0 * *$ & $1535.0^{*}$ & $5143.70 * *$ & $9.90 *$ & $35.90 \mathrm{~ns}$ & $14.50^{*}$ & $66.50^{*}$ & $12.13 \mathrm{~ns}$ & $1581297.0^{*}$ & $487.8^{*}$ \\
\hline Methanol & 5 & $155146.6 *$ & $247.0^{*}$ & $359.00^{*}$ & $0.82 \mathrm{~ns}$ & $62.50 \mathrm{~ns}$ & $0.26 \mathrm{~ns}$ & $6.70^{*}$ & $49.15 \mathrm{~ns}$ & $3527990.0 *$ & $285.6^{*}$ \\
\hline $\mathrm{D} \times \mathrm{M}$ & 5 & $35245.3 \mathrm{~ns}$ & $15.30 \mathrm{~ns}$ & $43.65 \mathrm{~ns}$ & $2.50 \mathrm{~ns}$ & $72.80 \mathrm{~ns}$ & $0.22 \mathrm{~ns}$ & $1.18 \mathrm{~ns}$ & $42.70 \mathrm{~ns}$ & 2277849.0ns & $153.8 \mathrm{~ns}$ \\
\hline Error & 22 & 37767.1 & 25.13 & 68.08 & 1.25 & 45.39 & 1.36 & 2.78 & 38.51 & 1019465.0 & 76.8 \\
\hline CV (\%) & _- & 12.2 & 8.75 & 19.40 & 26.20 & 22.20 & 19.40 & 10.07 & 25.00 & 18.3 & 7.8 \\
\hline
\end{tabular}

ns, *, **: No significant, significant at 5 and $1 \%$ levels of probability

Table 2: Mean comparison effect of drought stress and methanol on yield and yield components of soybean

\begin{tabular}{|c|c|c|c|c|c|c|c|c|c|c|c|}
\hline & Treatment & $\begin{array}{l}1000 \text { seed } \\
\text { Weigh } \\
(\mathrm{g})\end{array}$ & $\begin{array}{l}\text { Height } \\
(\mathrm{cm})\end{array}$ & $\begin{array}{l}\text { No. of } \\
\text { pod }\end{array}$ & $\begin{array}{l}\text { No. of } \\
\text { hollow } \\
\text { pod }\end{array}$ & $\begin{array}{l}\text { Harvest } \\
\text { index }\end{array}$ & $\begin{array}{l}\text { Diameter } \\
\text { stem }\end{array}$ & $\begin{array}{l}\text { No. of } \\
\text { branch }\end{array}$ & $\begin{array}{l}\text { Height of } \\
1 \text { st branch } \\
(\mathrm{cm})\end{array}$ & $\begin{array}{l}\text { Total } \\
\text { biomass } \\
\left(\mathrm{kg} \mathrm{h}^{-1}\right)\end{array}$ & $\begin{array}{l}\text { Seed } \\
\text { yield } \\
\left(\mathrm{kg} \mathrm{h}^{-1}\right)\end{array}$ \\
\hline & T1 & $115.45 \mathrm{a}$ & $1675.5 \mathrm{a}$ & $54.36 \mathrm{a}$ & $3.7 b$ & $31.33 \mathrm{a}$ & $6.65 \mathrm{a}$ & $16.94 a$ & $5.01 \mathrm{a}$ & $6151.1 \mathrm{a}$ & $1675.59 a$ \\
\hline \multirow[t]{2}{*}{ Drought } & $\mathrm{T} 2$ & $108.13 b$ & $1438.98 b$ & $30.45 b$ & $4.77 \mathrm{a}$ & $29.33 \mathrm{a}$ & $5.38 b$ & $14.22 b$ & $6.17 \mathrm{a}$ & $4825.4 b$ & $1438.98 b$ \\
\hline & Methanol (0) & $110.35 b$ & $55.01 \mathrm{c}$ & $40.80 \mathrm{bc}$ & $3.63 \mathrm{a}$ & $26.26 \mathrm{a}$ & $6.123 \mathrm{a}$ & $15.13 b c$ & $3.90 \mathrm{~b}$ & $5480.6 b$ & $1436.00 \mathrm{bc}$ \\
\hline Foliar & Methanol (7\%) & $114.35 \mathrm{ab}$ & $60.82 \mathrm{abc}$ & $44.48 \mathrm{ab}$ & $4.68 \mathrm{a}$ & $33.99 a$ & $6.05 \mathrm{a}$ & $15.5 \mathrm{abc}$ & $4.6 \mathrm{ab}$ & $4791.0 \mathrm{~b}$ & $1609.00 \mathrm{ab}$ \\
\hline Application & Methanol (14\%) & $106.65 b$ & $62.26 \mathrm{ab}$ & $47.24 \mathrm{a}$ & $4.02 \mathrm{a}$ & $29.61 \mathrm{a}$ & $6.15 \mathrm{a}$ & $16.48 \mathrm{ab}$ & $4.5 \mathrm{ab}$ & $6265.0 \mathrm{a}$ & $1623.90 \mathrm{ab}$ \\
\hline \multirow[t]{4}{*}{ Methanol } & Methanol (21\%) & $124.5 \mathrm{a}$ & $63.30 \mathrm{a}$ & $53.22 \mathrm{a}$ & $4.45 \mathrm{a}$ & $27.99 \mathrm{a}$ & $6.21 \mathrm{a}$ & $17.17 \mathrm{a}$ & $4.9 \mathrm{ab}$ & $6574.0 \mathrm{a}$ & $1811.00 \mathrm{a}$ \\
\hline & Methanol (27\%) & $108.7 b$ & $56.33 b c$ & $37.94 b$ & $4.33 \mathrm{a}$ & $34.33 \mathrm{a}$ & $5.65 \mathrm{a}$ & $14.84 b c$ & $11.38 \mathrm{a}$ & $4902.0 \mathrm{~b}$ & $1517.10 \mathrm{bc}$ \\
\hline & Methanol (35\%) & $106.3 b$ & $46.03 \mathrm{~d}$ & $30.92 \mathrm{c}$ & $4.38 \mathrm{a}$ & $29.26 \mathrm{a}$ & $5.91 \mathrm{a}$ & $14.35 \mathrm{c}$ & $4.10 \mathrm{~b}$ & 4791.1b & $1352.10 \mathrm{c}$ \\
\hline & LSD & 10.49 & 6.00 & 9.80 & 1.34 & 8.06 & 1.30 & 1.90 & 7.40 & 1208 & 231.60 \\
\hline
\end{tabular}

Mean followed by similar letters in each column are not significant by different at $5 \%$ levels 
Interestingly, grain yield was reduced with increase in amount of methanol from $28-35[\mathrm{v} / \mathrm{v}]$ so that their yield were less than control probably due to decrease in number of filled pod and plant height. (Fig. 2). More over, there were no significant differences between 7, 21 and 35 [v/v] methanols. Result of mean comparison (Table 2) showed that the most plant height was related to 14 and $21[\mathrm{v} / \mathrm{v}]$ methanols, 63.3 and 62.26 respectively, which had significant difference with control and other treatments but not each other (Fig. 4). Height of main stem increased with increase in amount of methanol up to $21 \%$ [v/v] methanol but use of more than $21 \%$ [v/v] decreased plant height so that it was less than that of control plant in $55 \%[\mathrm{v} / \mathrm{v}]$. Also effect of drought stress on soybean 1000 grain weight resulted in reduction of grain yield (Fig. 10).

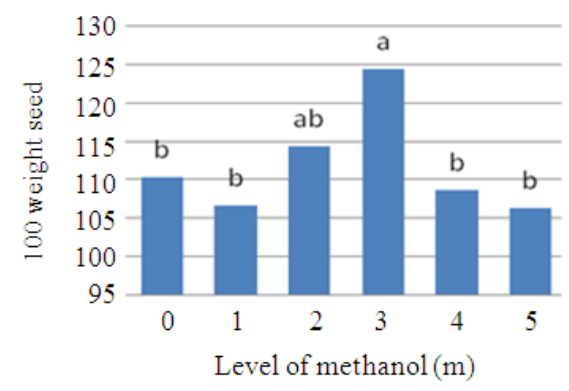

Fig. 3: Effect of methanol on yield seed

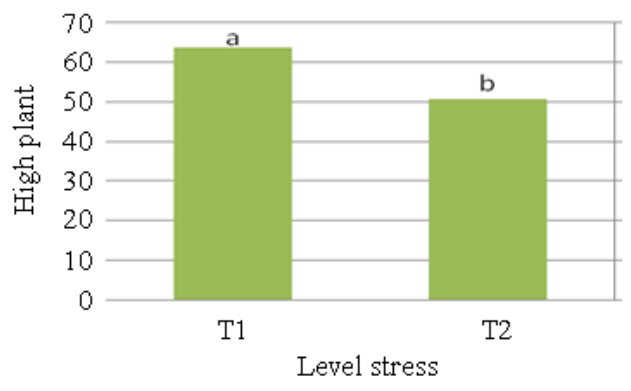

Fig. 4: Effect of drought stress on height

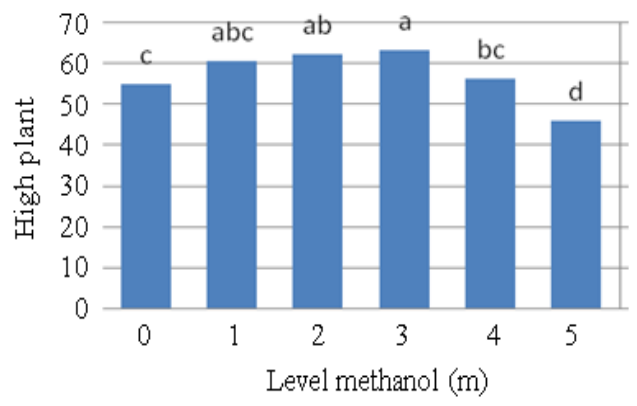

Fig. 5: Effect of methanol on height
Harvest index decreased as a result of reduction in yield and biomass, yet there were no significant differences between drought stresses (Fig. 7). Highest stem diameter $6.65 \mathrm{~cm}$, number of maturated pod 54.36 and number of branch 16.92 were (Fig. 5) related to T1 treatment and highest number of hollow pod was related to T2, based on mean comparison table (Table 2). In other hand, plant height and harvest index were not significantly affected with the highest mean related to T1 (Fig. 8).

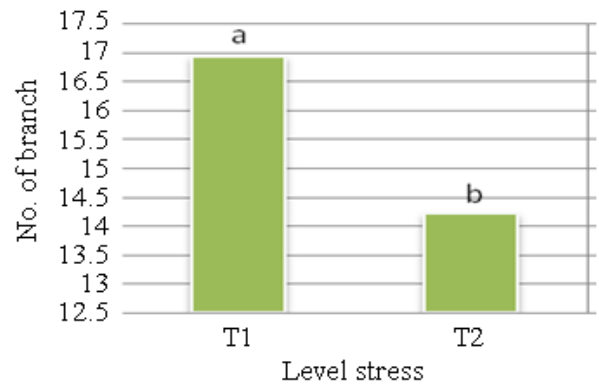

Fig. 6: Effect of drought stress on number of branch

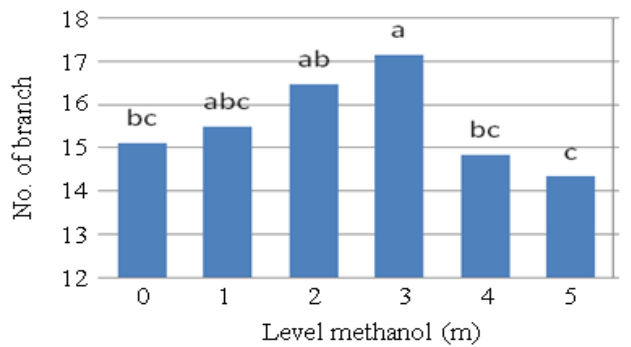

Fig. 7: Effect of methanol on number of branch

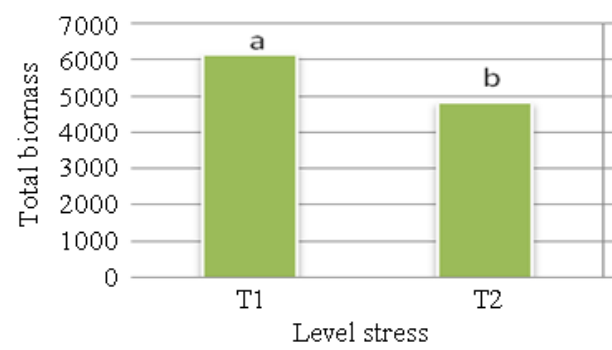

Fig. 8: Effect of drought stress on total biomass

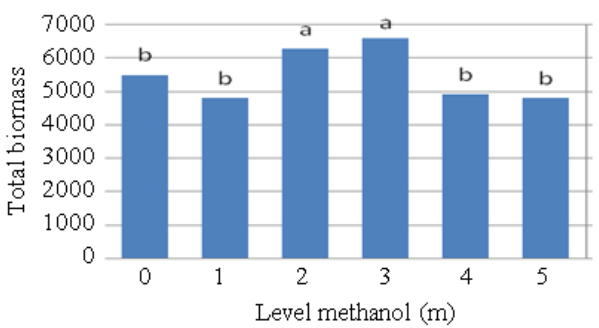

Fig. 9: Effect of methanol on total biomass 


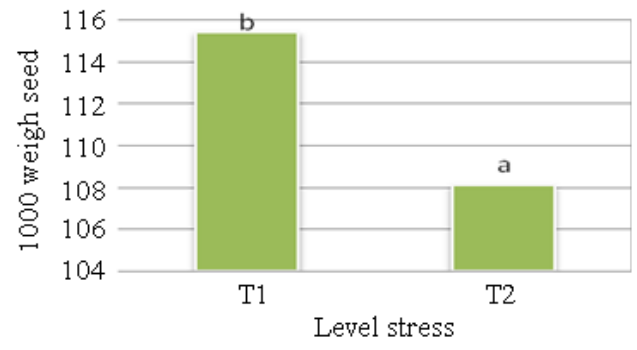

Fig. 10: Effect of drought stress on 1000 weigh seed

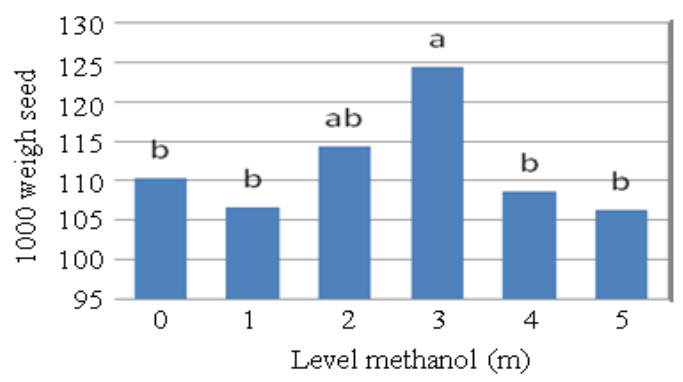

Fig. 11: Effect of methanol on 1000 weigh seed

Mean 1000 grain weight comparison (Table 2) showed that the highest mean was related to $21 \% \quad[\mathrm{v} / \mathrm{v}]$ methanol $124.5 \mathrm{~g}$ (Fig. 11). Meanwhile there were no significant differences between other treatments. Data analysis of soybean branch number showed that there were significant differences ( $p>0.05)$ between methanol treatments. Besides, mean comparison results (Table 2) showed that the highest mean were related to $\mathrm{m} 2$ and m3 with the mean of 17.7 and 16.68 , respectively (Fig. 6). These treatments have significant differences with other treatments and control plants. Branch number increased with increase in amount of methanol up to $21 \%[\mathrm{v} / \mathrm{v}]$ but it decreased with application of 27 and $35 \%[\mathrm{v} / \mathrm{v}]$ methanol since later treatments has less plant height and biomass, it may leads to less branch number in foregoing treatments(Fig. 6). Methanol treatments differently affected soybean total biomass so that M2 and M3 had significant differences with other treatments and control but not with each other. The least amount of biomass was related to M1 and M5 treatment (Fig. 9). More total biomass obtained with increase in methanol from $7-21 \%[\mathrm{v} / \mathrm{v}]$ but more methanol gradually decreased biomass. So that biomass related to 27 and $35 \%[\mathrm{v} / \mathrm{v}]$ methanol was less than that of control.

\section{DISCUSSION}

Drought stress is one of the important soybean growth limiting factor which decreases plant growth during vegetative stage. Many researchers believe that amount of crop water use determine plant growth and development. Meanwhile plants may injure under non optimal access of water at any $\operatorname{stage}^{[4,7,8]}$. Daneshian et al $^{[8]}$, introduced plant height as a drought tolerance indices and declared that tall soybean cultivar had more dry weight. This study showed that drought stress effected on all characters analyses. These results are in consistent with results of ${ }^{7,8]}$, and 2005 who declared that soybean yield decreases with increase in drought stress intention but main factor reducing yield under stress condition is reduction in grain per pod due to flower abscission during flowering stage ${ }^{[7,8]}$. Other investigators reported that most of investigated traits especially grain yield were affected by stress. These results are in line with result of ${ }^{[7,8,14,25,39]}$. This study showed that levels of methanol effected on all characters analyses. According to Benson and Nonomura $^{[5]}, 10-50 \%[\mathrm{v} / \mathrm{v}]$ methanol spray increase plant growth and yield due to reduction of photo respiration rate and increase in cell turgescence as well ${ }^{[32]}$. Consider increase in growth of wheat, radish, pea, peanut and tomato as a result of methanol spray has reported too ${ }^{[30,34,35,38]}$. This study showed that levels of methanol effected on all characters analyses. Increase in grain yield resulted from increase in 1000 grain weight, height, biomass, number of branches and number of pod per plant. Interestingly, grain yield was reduced with increase in amount of methanol from 28$35(\mathrm{v} / \mathrm{v})$ so that their yield were less than control probably due to decrease in number of filled pod and plant height (Fig. 3). Moreover, there were no significant differences between 7, 21 and $35(\mathrm{v} / \mathrm{v})$ methanol. These results are in consistent with results of Safarzad et al. ${ }^{[38]}$, who reported that methanol spray increased $20-50 \%$ yield of ground nut ${ }^{[38]}$. Also Li et al. ${ }^{[24]}$ declared that grain yield, grain weight and number of pod in methanol treatment plants were significantly higher than that of control plants and $25(\mathrm{v} / \mathrm{v})$ methanol spray had the most positive effect on growth and yield of soybean ${ }^{[24]}$. These results are in consistent with results of ${ }^{[5,6,29,34-36,40]}$, who reported that methanol spray increased 20 to $50 \%$ yield of ground nut. This study showed that level of methanol effected on height. These results are in line with that of ${ }^{[38]}$ who reported that highest ground nut height obtained the same results ${ }^{[5,6,29-31,34,35]}$. This study showed that level of methanol effected on biomass reduction. Furthermore, increase in methanol decreased leaf area duration and accelerated leaf senescence (data not shown) may be because this amount of methanol concentration may induced senescence signals and depleted leaf nutrition which in turn resulted in biomass reduction which is in 
line with ${ }^{[5,36,40]}$. Some investigations indicated that application of methanol on crops encountering water deficit increase crop biomass but decreases biomass of non stressed crops $^{[5,15,27,33]}$. Yet, there were no significant differences among other treatments. Based on result of variance analysis, application of methanol had no significant effect on number of hollow pod which is in line with results of ${ }^{[27,29,34,35]}$. Also, mean comparison of traits such as height of plant up to first branch, stem diameter and harvest index showed that non of methanol spray treatments had significant influence on these traits. Increase (Table 2) of number of matured and hollow pods showed that significant differences exist between various treatments so that highest number of matured pods was obtained from 21 , 14 and $7 \%[\mathrm{v} / \mathrm{v}]$ methanol which was resulted from higher pod and crop growth rate and leaf area and chlorophyll may be responsible for biomass escalation which is confirmed in our study. Some investigation related to effect of methanol spry on crop growth and yield indicated that spry of methanol on water deficit exposure crops increases their biomass but decreases biomass of control plants ${ }^{[31,34,36,40]}$. These results are in line with that of ${ }^{[29,38,40]}$, who reported that extra application of methanol cause to decline in branch number. Number of filled pod increased with increase of methanol up to $21 \%$ [v/v]. Future increase of methanol (27 and $35 \% \mathrm{v} / \mathrm{v})$ lead to decrease in matured pod number even less than control. It shows that methanol can affect crop $\mathrm{CO} 2$ assimilation. Photo respiration can be minimized with methanol spry, since $25 \%$ of carbon wastes during photo respiration ${ }^{[10,26,38,40]}$ Spray of methanol on drought encountering plants prevents loose of their biomass. These results are in line with that of ${ }^{[5,6,13,29,34-36,35,13]}$.

\section{CONCLUSION}

Application of Methanol on some physiological properties of soybean were effective and 14 and $20 \%$ volumetric percentage (v/v) of Methanol were known the best concentration for more grain yield and Growth, also Drought stress on some physiological properties were effective and the interactions of Methanol levels and drought stress was no significant. Application of Methanol up to $21 \%(\mathrm{v} / \mathrm{v})$ on some physiological properties had the positive effects and upper than that had negative and poisonous effects on soybean.

\section{REFERENCES}

1. Ali, S.K.L. and M.C. Mazumdar. 1991. Studies on pectin content of some fruits and plant parts. Sci. Cult., 57: 256.
2. Nonomura, A.M. and A.A. Benson, 1997. Methods and compositions for enhancing carbon fixation in plants. United States Patent, number 55974. http://www.patentstorm.us/patents/5597400/claims.html

3. Rodriguez Andres, A., J.J. Lazaro, A. Chueca, R. Hermoso and J. Lopez Gorge, 1990. Effect of alcohols on the association of photosynthetic FBPase to thylakoid membranes. Physiol. Plant, 78: 409-413.

http://www3.interscience.wiley.com/journal/11937 0877/abstract

4. Brown, E.A., C.E. Canviness and D.A. Brown, 1985. Response of selected soybean cultivars to soil moisture deficit. Agron. J., 77: 274-278. http://agron.scijournals.org/cgi/content/abstract/77/2/274

5. Benson, A.A. and A.M. Nonomura, 1992. The path of carbon in photosynthesis: Methanol inhibition of glycolic acid accumulation. Photosynth. Res., 34: 196. http://www.pnas.org/content/89/20/9794.abstract

6. Downie, A., S. Myazaki and H. Bohnert et al., 2004. Expression profiling of the response of Arabidopsis thaliana to methanol stimulation. Phytochemistry, 65: 2305-2316. DOI: 10.1016/j.phytochem.2004.07.006

7. Daneshian, J. and D. Zare, 2005. Diversity for resistance drought on soybean. J. Agric. Sci., 1: 23-50.

8. Daneshian, J. and P. Jonobi, 2001. Effect of drought stress and different calcium on characters soybean. Agric. Sci., 1: 95-108.

9. Desclaux, D., T.T. Huynh and P. Roumet, 2000. Identification of soybean plant characteristics that indicate the timing of drought stress. Crop Sci., 40: 716-722. http://cat.inist.fr/?aModele=afficheN\&cpsidt=1418229

10. Fall, R. and A.A. Benson, 1996. Leaf methanol, the simplest natural product from plants. Trends Plant Sci., 1: 296-301.

11. Feibert, E.B.G., S.R. James, K.A. rykbost, A.R. Mitchell and C.C. Shock, 1995. Potato yield and quality not changed by foliar-applied methanol. HortScience, 30: 494-495. http://cat.inist.fr/?aModele=afficheN\&cpsidt=3631866

12. Galbally, E. and W. Kirstine, 2002. The production of methanol by flowering plants and the global cycle of methanol. J. Atmos. Chem., 43: 195-229.

13. Gout, E., S. Aubert, R. Bligny, F. Rébeillé, A.R. Nonomura, A.A. Benson and R. Douce, 2000. Metabolism of methanol in plant cells. Carbon-13 nuclear magnetic resonance studies. Plant Physiol., 123: 287-296. http://www.plantphysiol.org/cgi/content/abstract/1 23/1/287 
14. Ghorbanli, M. and M. Niakan, 2005. The effect of drought stress on soluble sugar, total protein, proline, phenolic compound, chlorophyll content and nitrate reductase activity in soybean (Glycine max L. Cv. Gorgan 3). J. Sci., 5: 537-550. http://www.sid.ir/En/ViewPaper.asp?ID=87546\&v $\operatorname{arStr}=5 ;$ GHORBNLI\%20M.,NIAKAN\%20M.;JO URNAL\%20OF\%20SCIENCE\%20(TEACHER\%2 OTRAINING\%20UNIVERSITY);SPRINGSUMMER\%202005;5;1-2;537;550

15. Cossins, E.A., 1964. The utilization of carbon-1compounds by plants. Can. J. Biochem., 42: 1793-1802. DOI: $10.1139 / \mathrm{BCB}-42-12-1793$

16. Heins, R., 1980. Inhibition of ethylene synthesis and senescence in carnation by ethanol. J. Am. Soc. Hortic. Sci., 105: 141-144.

17. Hemming, D.J.B., R.S. Criddle and L.D. Hansen, 1995. Effects of methanol on plant respiration. J. Plant Physiol. 146: 193-198. http://www.springerlink.com/content/x0314403205 55706/

18. Hanson, A.D. and S. Roje, 2001. One-carbon metabolism in higher plants. Annu. Rev. Plant Physiol. Plant Mol. Biol. 52: 119-137. http://www.ncbi.nlm.nih.gov/pubmed/11337394

19. Ivanova, EG., N.V. Dornina and Y.A. Trotsenko, 2001. Aerobic methylbacteria are capable of synthesizing auxins. Microbiology, 70: 392-397. http://www.springerlink.com/content/x0314403205 55706/

20. Ivanova, E.G., N.V. Dornina, A.O. Shepelyakovskaya, A.G. Laman, F.A. Brovko and Y.A. Trotsenko, 2000. Facultative obligate aerobic methylobacteria synthesize cytokenins. Microbiology, 69: 646-651. http://www.springerlink.com/content/j76172n82r5 07262/

21. Joshi, J., 1996. Foliar applied methanol and nitrogen for increased productivity on leguminous Plant. Plant Physiol., 45: 197-209.

22. Kesselmeier, J. and M. Staudt, 1999. Biogenic Volatile Organic Compounds (VOC): An overview on emission, physiology and ecology. J. Atmosph. Chem., 33: 23-88. http://www.springerlink.com/content/ju6884w5u86 3r040/

23. Kishitani, S., T. Takanami, M. Suzuki, M. Oikawa and S. Yokoi et al., 2000. Compatibility of glycinbetaine in rice plants: Evaluation using transgenic rice plants with a gene for peroxisomal betaine aldehyde dehydrogenase from barley. Plant Cell Environ., 23: 107-114.
24. Yuncong, L.I., G. Gupta, J.M. Joshi and A.K. Siyumbano, 1995. Effect of methanol on soybean photosynthesis and chlorophyll. J. Plant Nutr., 18: 1875-1880.

http://cat.inist.fr/?aModele $=$ afficheN\&cpsidt $=3625$ 188

25. Linkemer, G., J.E. Board and M.E. Musgrave, 1998. Water logging effect on growth and yield components in late planted soybean. Crop Sci., 36: 1576-1584.

http://cat.inist.fr/?aModele $=$ afficheN\&cpsidt $=1632$ 169

26. Lawlor, D.W., 1987. Photosynthesis: Metabolism, Control and Physiology. Longman, Harlow, ISBN: 0470206810, pp: 262.

27. Madhaiyan, T., S. Poonguzhali, S.P. Sundaram and S.A. Tongmin, 2006. A new insight into foliar applied methanol influencing phylloplane ethylotrophic dynamics and growth promotion of cotton (Gossypium hirsutum L.) and sugarcane (Saccharum officinarum L.). Environ. Exp. Bot., 57: 168-176.

http://cat.inist.fr/?aModele $=$ afficheN\&cpsidt $=1778$ 843

28. Moran, J.F., M. Becana, I. Iturbe-Ormaetxe, S. Frechilla, R.V. Klucas and P. Aparicio-Teho, 1994. Drought induces oxidative stress in pea plants. Planta, 194: 346-352.

http://www.springerlink.com/content/g7635q7n170 r5410/

29. Makhdum, M.I., M.N.A. Malik, S.U. Din, F. Ahmad and F.I. Chaudhry, 2002. Physilogical response of cotton to methanol foliar application. J. Res. Sci., 13: 37-43.

30. McGiffen, M.E. and J.A. Manthey, 1996. The role of methanol in promoting plant growth: A current evaluation. HortScience, 31: 1092-1096. http://www.fao.org/agris/search/display.do?f=./199 8/v2403/US1997052451.xml;US1997052451

31. Nonomura, A.M. and A.A. Benson, 1992. The path of carbon in photosynthesis: Improved crop yields with methanol. Proc. Natl. Acad. Sci. USA., 89: 9794-9798. http://www.pnas.org/content/89/20/9794.abstract

32. Nemecek-Marshall, M., R.C. MacDonald, J.J. Franzen, C.L. Wojciechowski and R. Fall, 1995. Methanol emission from leaves: Enzymatic detection of gasphase methanol and relation of methanol. Fluxes to stomata conductance and leaf development. Plant Physiol., 108: 1359-1368. http://www.plantphysiol.org/cgi/content/abstract/1 08/4/1359 
33. Obendorf, R.L., J.L. Koch, R.J. Gorecki, R.A. Amable and M.T. Aveni. 1990. Methanol accumulation. in maturing seeds. J. Exp. Bot., 41: 489-495. http://cat.inist.fr/?aModele $=$ afficheN\&cpsidt $=6902$ 902

34. Ramberg, H.A., J.S.C., Bradley, J.S.C., Olson, J.N. Nishio, J. Markwell and J.C. Osterman. 2002. The role of methanol in promoting plant growth: An update. Rev. Plant Biochem. Biotechnol: 1:113-126.

http://www.springerlink.com/content/e6k1q754753 $1145 \mathrm{u} /$

35. Ramirez, I., F. Dorta, V. Espinoza, E. Jimenez, A. Mercado and H. Pena-Cortes. 2006. Effects of foliar and root applications of methanol on the growth of arabidopsis, tobacco and tomato plants. J Plant Growth Regul., 25: 30-44. http://www.springerlink.com/content/e6k1q754753 $1145 \mathrm{u} /$

36. Theodoridou, A., D. Dornemann and K. Kotzabasis, 2002. Light-dependent induction of strongly increased microalgal growth by methanol. Biochim. Biophys. Acta, 1573: 189-198. http://cat.inist.fr/?aModele=afficheN\&cpsidt=1397 6669

37. Robinson, S.P. and G.P. Jones, 1986. Acclimation of glycinbetaine in choloroplasts provides osmotic. Adjustment during salt stress. Aust. J. Plant Physiol., 13: 659-668. http://www.publish.csiro.au/paper/PP9860659

38. Safarzade Vishgahi M.N., G.H. Normohamadi, E. Majidi Haravan, B. Rabiei, 2005. Effect of methanol on peanut Growth and yield (Arachis hypogaea L.). J. Agric. Sci., 2005: 103-188.
39. Sivakumar, M.V.K. and R.H. Shaw, 1978. Relative evaluation of water stress for soybean. Agron. J. 70: 619-623.

http://agron.scijournals.org/cgi/content/abstract/70/ $4 / 619$

40. Zbiec, I., S. Karczmarczyk and C. Podsiadlo, 2003. Response of some cultivated plants to methanol as compared to supplemental irrigation. Elect. J. Polish Agric. Univ.: Agron., 6: 1-7. http://www.ejpau.media.pl/volume6/issue1/agrono my/art-01.html 